\title{
MODEL PERMAINAN KREATIF UNTUK MEMOTIVASI SISWA DALAM PEMBELAJARAN BOLA VOLI PADA SISWA KELAS V SD
}

\author{
Roni Albar ${ }^{1}$, KhairilAkbar ${ }^{2}$, Indria Susilawati ${ }^{3}$ \\ ${ }^{1}$ Mahasiswa Lulusan Program Studi Penjaskesrek Tahun 2018 \\ ${ }^{2,3}$ Dosen STKIP Melawi
}

J1. RSUD Melawi km. 04 Kec.Nanga Pinoh Kab. Melawi Kalimantan Barat ronialbar.75@gmail.com, khairilakbar89@gmail.com,smile_indria@yahoo.com

\begin{abstract}
The general objective of this study is to motivate students in learning the bottom service volleyball game for grade V students of SD Negeri 09 Tanjung Lay. Specific purpose is to find out how much influence the creative game model has on students' motivation in volleyball games in grade V 09 Tanjug Lay Elementary School.This study uses classroom action research (Clasroom action research) using action cycles. In this action research, using the models described are: Planning (Action), Action (Action), Observation (Observation) and Reflection (Reflection).The findings of the study were: the results of student motivation increased, because in the first cycle the average value of students was 57.73 while in the second cycle the average value of students was 74.54 had reached the predetermined criteria.Based on the results of the study it can be concluded that through creative game models can motivate students in learning volleyball games in class $\mathrm{V}$ SD Negeri 09 Tanjung Lay. In this study, it can be suggested, the health teacher is expected to be able to plan and develop creativity and be more innovative in the learning process in an effort to improve student competencies, especially in choosing learning methods.
\end{abstract}

Key Words: Creative Games, Volleyball

Abstrak: Tujuan umum dari penelitian ini yaitu untuk memotivasi
siswa dalam pembelajaran permainan bola voli pada siswa kelas V SD
Negeri 09 Tanjung Lay. Tujuan khusus adalah Untuk mengetahui
seberapa besar pengaruh model permainan kreatif terhadap motivasi
siswa dalam permainan bola voli kelas V SD Negeri 09 Tanjug Lay.
Penelitian ini menggunakan penelitian tindakan kelas (Clasroom action
research) dengan menggunakan siklus tindakan. Pada penelitian
tindakan ini, menggunakan model yang dijelaskan yaitu: Rencana
(Planning), Tindakan (Action), Pengamatan (Observation) dan Refleksi
(Reflection).Hasil temuan penelitian adalah : hasil motivasi siswa
meningkat, karena pada siklus I nilai rata - rata siswa adalah 57.73
sedangkan pada siklus II nilai rata-rata siswa adalah 74.54 telah
tercapai kriteria yang telah ditetapkan.Berdasarkan hasil penelitian 


\section{Jurnal Pendidikan Jasmani Kesehatan dan Rekreasi(Penjaskesrek) \\ Volume 6, Nomor 1, Januari 2019}

dapat disimpulkan bahwa melalui model permainan kreatif dapat memotivasi siswa dalam pembelajaran permainan bola voli pada siswa kelas V SD Negeri 09 Tanjung Lay.Dalam penelitian ini, dapat disarankan, guru penjaskes diharapkan dapat merencanakan dan mengembangkan kreativitas dan lebih inovatif pada proses pembelajaran dalam upaya meningkatkan kompetensi siswa terutama dalam memilih metode pembelajaran.

Kata Kunci : Permainan Kreatif, Bola Voli

$\sqrt{\text { melaksanakan observasi di }}$ Sekolah Dasar Negeri 09 Tanjung Lay, peneliti menemukan bahwa banyak sekali model permainan atau cara mengajar yang dilakukan oleh guru di lapangan maupun dalam ruangan, yakni sebagai guru penjasorkes. Dalam mengajar di lapangan maupun dalam ruangan, tentunya seorang guru perlu memahami minat siswa dalam pembelajaran sehingga dapat memilih model permainan yang tepat.

Motivasi siswa dalam mengikuti pelajaran Penjasorkes dapat disebabkan oleh beberapa faktor, antara lain hobi siswa itu sendiri, ada yang ingin menjaga kesehatan badannya, dan ada juga yang ingin meluapkan kejenuhannya di lapangan dengan cara bermain bersama teman sebayanya. Seseorang melakukan aktivitas karena didorong oleh adanya faktor-fakor, kebutuhan biologis, insting, dan unsur-unsur kejiwaan yang lain memotivasi siswa dapat dilihat dari kesungguhan dalam mengerjakan aktivitas yang guru berikan. Apabila seorang siswa dalam melakukan suatu gerakan dengan rasa senang dan sungguh-sungguh, maka dapat disimpulkan siswa tersebut memiliki motivasi yang tinggi dalam melakukan gerakan atau aktivitas yang guru berikan.

Berdasarkan anggapan di atas, tentu saja akan mempengaruhi motivasi siswa dalam mengikuti pembelajaran Penjasorkes. Hal tersebut menguatkan fakta di lapangan bahwa masih ditemukan adanya siswa yang belum mengoptimalkan waktu pembelajaran dengan sebaik mungkin. Keadaan tersebut bisa dilihat dengan adanya siswa yang kurang antusias dalam mengikuti pelajaran. Siswa yang menganggap Penjasorkes tidak terlalu penting lebih memilih untuk duduk, 
berteduh, dan mengobrol pada saat proses pembelajaran berlangsung bahkan ada juga yang asyik bergurau dan bermain sendiri.

Pengenalan teknik dasar sangatlah penting dalam pembelajaran pendidikan jasmani untuk memudahkan proses balajar mengajar untuk tercapainya materi yang di sampaikan secara utuh dan juga untuk meningkatkan keterampilan gerak serta prestasi belajar siswa. Sehubungan dengan hal tersebut di atas maka peneliti tertarik untuk melakukan penelitian dengan judul "Model Permainan Kreatif untuk Memotivasi Siswa dalam Permainan Bola Voli Kelas V SD Negeri 09 Tanjung Lay”.

Berdasarkan latar belakang diatas maka identifikasi masalah pada penulisan ini ialah sebagai berikut: (1) Siswa kurang antusias dalam mengikuti proses pembelajaran karena pembelajaran yang berlangsung cenderung membosankan. (2) Siswa hanya dituntut untuk mendengarkan penjelasan dari guru sehingga menyebabkan siswa kurang aktif. (3) Saat proses pembelajaran berlangsung, beberapa siswa tidak serius dalam mengikuti pembelajaran. Berdasarkan latar belakang yang telah diuraikan diatas, maka peneliti dapat merumuskan permasalah adalah (1) Bagaimana model permainan kreatif untuk memotivasi siswa dalam permainan bola voli pada siswa kelas $\mathrm{V}$ SD Negeri 09 Tanjung Lay?., (2) Seberapa besar siswa termotivasi terhadap permaianan bola voli dengan model permainan kreatif?

Permainan bola voli adalah olahraga yang dapat dimainkan oleh anak-anak sampai orang dewasa wanita maupun pria. Dengan bermain bolavoli akan berkembang secara baik unsur-unsur daya pikir kemampuan dan perasaan. Di samping itu kepribadian juga dapat berkembang dengan baik terutama control pribadi, disiplin, kerjasama, dan rasa tanggung jawab terhadap apa yang diperbuatnya.

Teknik adalah cara melakukan atau melaksanakan sesuatu untuk mencapai tujuan tertentu secara efektif dan efisien.Teknik dasar dalam permainan bola voli terdiri dari teknik servis, teknik pas, teknik umpan, teknik smash dan teknik bendungan. 


\section{Jurnal Pendidikan Jasmani Kesehatan dan Rekreasi(Penjaskesrek) \\ Volume 6, Nomor 1, Januari 2019}

Bermain adalah melakukan sesuatu untuk bersenang-senang dan permainan adalah bermain Poewadarminta, (2003:689). Telah diakui kebenarannya bahwa hidup manusia sejak dari kecil tumbuh dengan melewati beberapa macam bentuk pengalaman bermain.Dari mempelajari perkembangan individu manusia beserta sejarahnya, dapat ditarik kesimpulan bahwa permainan itu ada. Oleh karena itu manusia tumbuh tidak dapat mengelakkan alam permainan. Anak-anak berkembang melewati bermacam-macam permainan sebagai kodrat yang alami Soemitro (1992:3).

Jadi bermain juga mengandung unsur pendidikan dimana dalam melakukan permainan bisa melatih anak untuk lebih kreatif dalam menentukan sesuatu tindakan, mengembangkan daya tangkap serta imajinasinya dapat berkerja sama, melatih kejujuran dan meningkatkan jiwa sosial.

Dari pendapat para ahli di atas dapat disimpulkan bahwa permainan adalah bagian dari kehidupan anak dan aktifitas bermain yang dilakukan dalam rangka mencari kesenangan serta kepuasan, namun bisa ditandai pencarian menang-kalah.Dalam penelitian ini peneliti ingin memotivasi siswa dengan menggunakan permainan 4 on 4 dalam pembelajaran bolavoli khususnya siswa kelas V SD Negeri 09 Tanjung Lay.

Aspek motivasi memegang peranan dalam kejiwaan seseorang, sebab motivasi merupakan salah satu faktor penentu sebagai pendorong tingkah laku manusia, sehingga dengan adanya motivasi seseorang dapat mendorong dirinya untuk lebih giat berlatih dan mencapai hasil yang maksimal. Menurut Uno (2014:1) motivasi adalah dorongan yang menggerakkan seseorang bertingkah laku, dorongan ini berada pada diri seseorang yang menggerakakkan untuk melakukansesuatu yang sesuai dengan dorongan dalam dirinya. Pendapat lain dari Walgito (2003: 220), mengatakan bahwa motivasi adalah sebuah keadaan individu atau organisme yang mempengaruhi perilaku ke arah tujuan. Menurut Gunarsa (2008: 47) motivasi adalah suatu kekuatan atau tenaga pendorong untuk melakukan sesuatu 


\section{Jurnal Pendidikan Jasmani Kesehatan dan Rekreasi(Penjaskesrek)}

Volume 6, Nomor 1, Januari 2019

hal atau menampilkan sesuatu prilaku tertentu.

Berdasarkan beberapa pendapat parah ahli di atas, dapat disimpulkan bahwa motivasi adalah seluruh proses gerakan termasuk situasi yang mendorong berupa dorongan, pengerak atau alasan yang timbul dan terdapat dalam diri seseorang untuk bereaksi/tidak bereaksi untuk menentukan arah aktivitas terhadap pencapaian tujuan.

\section{METODE PENELITIAN}

\section{Pelaksanaan Penelitian}

Metode dalam suatu penelitian harus tepat atau mengarah pada tujuan penelitian serta dapat di pertanggung jawabkan secara ilmiah sesuai dengan aturan yang berlaku, agar dalam penelitian tersebut dapat diperoleh hasil yang sesuai dengan yang diharapkan. Metode penelitian yang digunakan dalam penelitian ini adalah penelitian tindakan kelas. Dengan penelitian tindakan kelas peneliti dapat mencermati suatu obyek dalam hal ini siswa, menggunakan permainan kreatif untuk memotivasi siswa terhadap pembelajaran bola voli. Melalui tindakan yang sengaja dilakukan dengan tujuan tertentu dalam bentuk rangkaian siklus kegiatan. Dengan demikian perkembangan dalam setiap kegiatan dapat terpantau.

\section{Subjek, Objek dan Waktu Penelitian}

Subjek adalah siswa kelas V SD Negeri 09 Tanjung Lay dengan jumlah siswa sebanyak 11 orang, terdiri dari 6 orang siswa perempuan dan 5 orang siswa laki-laki. Sedangkan yang menjadi objek dalam Penulisan ini adalah memotivasi siswa pada permainan bola voli dengan model permainan kreatif

\section{Waktu Pelaksanaan Penelitian}

Penelitian ini dilaksanakan pada SD Negeri 09 Tanjung Lay.Alasan penulis memilih tempat penelitian tersebut, karena peneliti pernah melakukan praktek lapangan di sekolah tersebut.

\section{Prosedur Penelitian}

Pelaksanaan Penelitian Tindakan Kelas ini melalui beberap tahapan tahapan tersebut terdiri dari perencanaan tindakan, pelaksanaan tindakan, pengamatan tindakan, dan refleksi tindakan sebagai berikut :

Pada setiap siklus. 


\section{Perencanaan tindakan}

Membuat rencana pembelajaran dengan mengacu kepada tindakan yang diterapkan dalam penelitian tindakan kelas. Instrumen yang digunakan dalam siklus tindakan kelas. Penyusunan alat evaluasi pembelajaran.

\section{Pelaksanaan Tindakan}

Deskripsi tindakan yang akan dilakukan, sekenario kerja tindakan dan prosedur tindakan yang diterapkan.

\section{Observasi}

Peneliti mengobservasi pengetahuan selama proses pembelajaran berlangsung guru sebagai peneliti melakukan penilaian mengunakan lembar pengamatan yang dilakukan oleh teman sejawat.

\section{Repleksi}

Tahapan refleksi ini guru selaku peneliti mengumpulkan data hasil observasi atau evaluasi yang telah dilaksanankan untuk dianalisis dan diproses sehingga pada akhirnya dapat ditemukan suatu hasil terhadap kegiatan pembelajaran yang telah berlangsung dan akan diketahui apakah terdapat peningkatan.

\section{HASIL DAN PEMBAHASAN}

Berdasarkan tujuan peneliti lakukan maka tujuan yang ingin dicapai dalam penelitian ini adalah; untuk mengetahui peningkatan motivasi pembelajaraan bola voli khususnya dalam permainan bola voli melalui model permainan kreatif pada siswa kelas V SD Negeri 09 Tanjung Lay.

Penelitian tindakan kelas ini dilakasanakan di SD Negeri 09 Tanjung Lay yaitu pada kelas V yang berjumlah 11 orang siswa, dalam penelitian ini dilakukan dalam dua tahapan yaitu siklus I dan siklus II. Pada pembelajaran meningkatan motivasi siswa pada permainan bola voli dengan model permainan kreatif. Setiap siklus terdiri dari perencanaan, pelaksanaan, observasi dan refleksi. Berdasarkan tujuan penelitian yang penulis lakukan maka sasaran yang akan dicapai adalah untuk meningkatkan motivasi siswa pada pembelajaraan perminanbola voli.

Siklus pertama dilaksanakan selama satu kali pertemuan yaitu dengan materi pokok permainan bola besar yaitu permainan bola voli yang dibahas pada pertemuan ini adalah 


\section{Jurnal Pendidikan Jasmani Kesehatan dan Rekreasi(Penjaskesrek)}

Volume 6, Nomor 1, Januari 2019

memotivasi siswa pada pembelajaran permianan bola voli. Siklus pertama yang dilaksanakan satu kali pertemuan ini, dihadiri oleh 11 siswa.Kriteria keberhasilan siswa ditetapkan bila nilai 60. Tindakan yang dilakukan pada siklus ke-1 ini, yaitu: Proses pembelajara mengunakan model permainan kreatif,setelah siswa di ajarkan pembelajaran permainan kreatif dan selanjut setiap siswa melakukan permainan bola voli.

Dari kegiatan pembelajaran tersebut peneliti mendapat hasil yang dilakukan selama proses kegiatan pembelajaraan meningkatkan motivasi siswa pada pelajaran permai nan bola voli. Nilai rata-rata yang di peroleh siswa pada siklus I adalah 54,72. Pada siklus I ini masih belum mencapai nilai kriteria ketuntasan minimal.

Data tersebut diatas menunjukan bahwa pembelajaran meningkatkan motivasi siswa dalam pelajaran permainan bola dari jumlah siswa sebanyak 11 orang hanya ada 4 orang siswa yang dinyatakan tuntas dalam proses pembelajaaraan tersebut. Nilai motivasi siswa pada pembelajaraan bola voli yang paling tertinggi adalah
80 dan yang terendah adalah 40. Jumlah nilai siswa keseluruhannya 630 dibagi 11 Orang maka nilai rata-rata adalah 57.73 Dengan demikian rata-rata nilai motivai siswa pada pembelajaraan bola voli siklus pertama siswa masih kurang termotivasi.

Siklus kedua dilaksanakan dengan banyak siswa 11 orang. pada siklus II ini dan kriteria keberhasilan seperti yang ditetapkan pada siklus I. Tindakan yang dilakukan pada siklus II ini ditetapkan berdasarkan hasil refleksi pada siklus pertama. Kriteria keberhasilan siswa ditetapkan bila nilai 60 dan dari jumlah siswa yang hadir mendapat nilai rata - rata 60 - 100 . Proses pembelajara mengunakan model permainan kreatif, setelah siswa di ajarkan pembelajaran permainan kreatif.

Dari kegiatan pembelajaran tersebut peneliti mendapat hasil yang dilakukan selama kegiatan pembelajaraan meningkatkan motivasi siswa dalam permainan bola voli. Data tersebut diatas menunjukan bahwa pembelajaraan bola voli dari jumlah siswa sebanyak 11 orang dengan persentase ketuntasan11 orang, atau 


\section{Jurnal Pendidikan Jasmani Kesehatan dan Rekreasi(Penjaskesrek) \\ Volume 6, Nomor 1, Januari 2019}

$100 \%$ dan tidak tuntas sebanyak 0 orang, atau $0 \%$. Nilai pembelajaraan bola voli siswa yang paling tertinggi adalah 92,50 dan yang terendah adalah 62,50. Jumlah nilai siswa ke seluruhannya 824,50 dibagi 11 Orang maka nilai rata-rata adalah 74,95. Dengan demikian rata-rata pembelajaran bola voli pada siklus II dikatakan berhasil. Setelah melakukan penilaian terhadap proses pembelajaran bola voli peneliti melajutkan penilaian terhadap motivasi siswa.

Data tersebut diatas menunjukan bahwa motivasi siswa terhadap pembelajaraan permainan bola dari jumlah siswa sebanyak 11 orang dengan persentase ketuntasan 100\% dan tidak tuntas $0 \%$. Nilai motivasi siswa pada pembelajaaran permainan bola siswa yang paling tertinggi adalah 100 dan yang terendah adalah 60. Jumlah nilai siswa keseluruhannya 824,50 dibagi 11Orang maka nilai rata-rata adalah 74,95. Dengan demikian rata-rata nilai motivasi siswa dalam pembelajaraan permainan bola voli pada siklus II dikatakan berhasil.

\section{Pembahasan}

Pembelajaraan permainan bola voli siswa sangatlah rendah sehingga pontensi dan prestasi individual siswa tidak terasah hal ini menyebakan pembelajaran permainan bola voli belum tercapai pada tingkat keberhasilan

Rendahnya nilai pembelajaraan permainan bola voli siswa terlihat dari kondisi-kondisi sebagai berikut: (1) Siswa kurang antusias dalam mengikuti proses pembelajaran karena pembelajaran yang berlangsung cenderung membosankan. (2) Siswa kelas V SD Negeri 09 Tanjung Lay belum mengetahui teknik dasar permainan bola voli. (3) Sarana dan prasarana yang sangat kurang untuk menunjang kelancaran kegiatan belajar mengajar. (4) Siswa hanya mendengarkan penjelasan dari guru saat memulai pembelajaran sehingga menyebabkan siswa kurang afekif. (5) Saat proses pembelajaran berlangsung, beberapa siswa tidak serius dalam mengikuti pembelajaran.

Model permainan kreatif merupakan salah satu solusi dalam 
mengatasi rendahnya tingkat motivasi siswa dalam melakukan pembelajaraan permainan bola voli sebagaimana diuraikan diatas. Tindakan ini diterapkan sebanyak dua siklus terhadap siswa kelas V SD Negeri 09 Tanjung Lay, dan ternyata penelitian tentang model permainan kreatif untuk memotivasi siswa dalam Permainan Bola Voli Kelas V SD Negeri 09 Tanjung Lay menunjukan peningkatan yang signifikan.

Data tersebut di atas menunjukan bahwa terjadi peningkatan motivasi siswa pada pembelajaaran permainanbola voli, siklus I sebesar 57,73 dan pada siklus II sebesar 74,95.

Penelitian dapatlah disimpulkan dari siklus I dan siklus II dinyatakan sebagai berikut: Perbandingan tingkat ketercapaian jumlah nilai persentase dan nilai rata-rata minat motivasi siswa dalam pembelajaraan permainan bola voli service bawah pada kegiatan pembelajaran penjaskes di kelas V SD Negeri 09 Tanjung Lay menunjukan bahwa perbandingan jumlah nilai dari siklus I ke siklus II sebesar 16,81\%. Dengan demikian dapat disimpulkan bahwa model permainan kreatif untuk motivasi siswa pada Pembelajaraan permainan bola voli kelas V SD Negeri 09 Tanjung Lay.di katakan berhasil.

\section{SIMPULAN}

Pembelajaraan permainan bola voli sangatlah rendah sehingga pontensi dan prestasi individual siswa tidak terasah hal ini menyebakan siswa kurang termotivasi pada pembelajaran permainan bola belum tercapai pada tingkat keberhasilan. Model permainan kreatif merupakan salah satu solusi dalam mengatasi rendahnya tingkat nilai motivasi siswa dalam melakukan pembelajaraan permainan bola voli sebagaimana diuraikan diatas. Tindakan ini diterapkan sebanyak dua siklus terhadap siswa kelas V SD Negeri 09 Tajug Lay, dan ternyata penelitian tentang pembelajaraan dalam memotivasi siswa dalam pembelajaraan permainan Permainan Bola Voli dengan model permainan kreatif Pada Siswa Kelas V SD Negeri 09 Tanjung Lay menunjukan peningkatan yang signifikan.

Terjadi peningkatan motivasi siswa pada pembelajaaran bola voli , siklus I sebesar 57,73 dan pada siklus II 
sebesar 75,54. Peningkatan motivasi siswa pada pembelajaaran permainan bola siklus I dan Siklus II dalam penelitian ini, dapat lebih jelas terlihat Perbandingan tingkat ketercapaian jumlah nilai persentase dan nilai rata-rata motivasi siswa dalam pembelajaraan permainan bola voli pada kegiatan pembelajaran penjaskes di kelas V SD Negeri 09 Tanjung Lay menunjukan bahwa perbandingan jumlah nilai dari siklus I ke siklus II sebesar 16,81 .

Dengan demikian dapat disimpulkan bahwa model permainan kreatif untuk memotivasi siswa dalam pembelajaraan permainan bola voli pada siswa kelas V SD Negeri 09 Tanjung Lay dikatakan berhasil.

\section{DAFTAR PUSTAKA}

Aip Syari Fudin \& Muhadi, 1992. Interaksi dan motivasi belajar-mengajar. Jakarta: CV. Rajawali.

Arikunto, Suharsimi. 2002. Prosedur Penelitian: Suatu Pendekatan Praktis. Edisi

Revisi V. Jakarta: Rineka Cipta.
Astuti,S.D.2006. Motivasi siswa SMP $N 2$ Jetis Bantul Dalam Mengikuti Kegiatan Ekstrakurikuler Bola voli. skripsi program studi Pendidikan Jasmani Kesehatan dan Rekreasi Fakultas Ilmu Keolahragaan Universitas Negeri Yogyakarta.

Bidang Wasit PP. PBVSI. 2001. Peraturan Permainan Bola Voli Internasional. Jakarta: PP. PBVSI.

BSNP. 2006. Kurikulum Tingkat satuan pendidikan. Jakarta: Depdikbud

Depdiknas. 2003. Standar kompetensi mata pelajaran pendidikan jasmani. Jakarta: Depdiknas

Durwachter, G. 1984. Bola Voli Belajar dan Berlatih Sambil Bermain. Jakarta: PT. Gramedia. Eveline Siregar, 2010. Faktor-faktor pengaruh motivasi belajar. Jakarta: Gramedia

Gunarsa, S.D. 2008. Psikologi olahraga. Jakarta: PT. BPK Gunung muliya.

Hanafiah, N.\& Suhana, C. 2012. Konsep strategi pembelajaran. 
Bandung: $\quad$ PT $\quad$ Remaja

Rosdakarya.

Husdarta, 2010. Teori motivasi dan ukuranya analisis di bidang pendidikan. Jakarta: Bumi Aksara.

Koesyanto, Herry.2003. Belajar bermain Bola Vol ey. Semarang: FIK UNNES.

Kosasih, E. 1993. Olahraga Teknik dan program latihan, Jakarta: Akademika Presindo.

Kusumah, Wijaya dan Dedi Dwitagama. 2011 Mengenal Penulisan Tindakan Kelas. Jakarta: PT Indeks.

Kurniawan, $\quad$ Imam. 2005. Pembelajaran Pas Atas Menggunakan Sasaran Tembok

Dan Berpasangan Terhadap Kecakapan Pas Atas Dalam Permainan Bola

Voli Pada Ekstrakurikuler SMP 3 Patebon Kabupaten Kendal TahunPelajaran 2004/2005. Skripsi. Jurusan PJKR, Fakultas Ilmu Keolahragaan Universitas Negeri Semarang.

Mulyasa, E. 2002. Perinsip-perinsip dan teknik evaluasi pengajaran.
Bandung: $\quad$ PT $\quad$ Remaja Rosdakarya.

Muhajir, 2006.Pendidikan Jasmani Olahraga dan kesehatan. Jakarta Erlangga

Mylsidayu, A. 2014. Pisikologi olahraga. Bumi Aksara: Jakarta.

Nuril Ahmadi, 2007.mendesain model pembelajaran inovatif-progresif. Jakarta: kencanaPrenanda Media Group.

Nurhasan.2001. Tes dan Pengukuran Dalam Pendidikan Jasmani: Prinsip-

Prinsip dan Penerapanya. Jakarta: Diknas nem Dirtjen Olahraga.

Poewadarminta, 2003.Prinsip-prinsip dan teknik evaluasi pengajaran. Bandung: PT Remaja Rosda Karya.

Purwanto, N.2004. Psikologi pendidikan. Bandung: PT Remaja Rosda karya.

Purnama. 2016. Motivasi Mengikuti Permainan Bola Basket dalam Pembelajaran Pendidikan Jasmani Olah raga dan Kesehatan Peserta Didik Putri Kelas XI SMA Negeri 2 Wonogiri Jawa Tengah. 
Rusman,

2010.Model-Model

Pembelajaran. Jakarta: Raja

Grafindo Persada.

Sardiman, A.M 1990.interaksi dan

motivasi

belajar-mengajar.jakarta:CV.

Rajawali

Shadiq, 2010. Pengertian kreativitas dan belajar adaptif (online).

http://fkip-unpak.Org/teti. html

Slameto, 2003. Belajar dan faktor-faktor yang mempengaruhinya.Jakarta:

Rineka cipta.

Soemitro, 1992. Implementasi belajar \& pembelajaran. Bandung: Remaja Rosda Karya.

Suharno, H.P.1993.Ilmu coaching umum. Yogyakarta: IKIP Yogyakarta Pres

Sukintaka,1992. Teori pendidikan jasmani. Yokyakarta:Esa Grafika.

Suyono \& Hariyanto, 2015. Implementasi belajar \& Pembelajaran. Bandung: Remaja Rosdakarya.

Trianto, 2009. Mendesain Model Pembelajaran Inovatif-progresif.
Jakarta: Kencana Prenanda Media Group

Uno, H.B.2014.Teori Motivasi Dan Ukurannya analisis di bidang pendidikan. Jakarta: Bumi Aksara.

Walgito,B. 2003. Pengantar pisikologi umum. Yogyakarta: ANDI.

Wiriaatmadja, Rochiati. 2009. Metode penulisan tindakan Kelas. Bandung: PT. Remaja Rosdakarya.

Yunus, M. 1992. Olahraga pilihan bola voli.Jakarta: Dirjen Dikti Debdikbut. 